\author{
冨川 昌義 ${ }^{\circ}$ (工学院大院), 中村 瑞木(工学院大院) \\ 荻巣 宏幸(工学院大学), 飯田 明由(工学院大学)
}

\title{
Visualization of vorticity field around a flying insect
}

\author{
Masayoshi FUKAWA, Mizuki NAKAMURA, Hiroyuki OGISU and Akiyoshi IIDA
}

\begin{abstract}
The purpose of this research is to clarify the generation mechanism of aerodynamic lifting force of a flying insect. For this purpose, aerodynamic force and flow field were measured with a micro load-cell system and dynamic PIV system. As a result, negative pressure caused by leading-edge vortices makes large lifting-force in the downstroke process. Although the leading-edge vortices can be observed even in the case of upstroke process, lifting-force was not generated. Because of the distance between the vorticity core and wing was larger than that of the downstroke process. Therefore, the distance between the core and wing plays an important role with aerodynamic force generation.
\end{abstract}

Keywords: Micro Air Vehicle, Dynamic PIV, Flapping airfoils, Aerodynamic force.

\section{1. 緒論}

近年，極限環境観察や被災地の調查などにおいて，探索 地域を飛び回りながら情報収集ができる小型飛翔体 (MAV : Micro Air Vehicle)の開発が望まれている.MAV の運用例として倒壞した建物内での活動を想定した場合， ホバリング飛行や急旋回といった高度な飛行性能を両立 寸ることが必須課題である. 現在, 世界各国で様々な MAV が開発されているが 1)，上記の様な飛行性能を両立した MAV は未だ開発させていない，一方で，昆虫に代表され るような羽ばたき翼による飛翔では，実際にホバリング飛 行と急旋回を耐立している。このことから，昆虫や小型の 鳥類を規範とした MAV の開発が勢力的に進められており 2)，特に低レイノルズ数域における翅まわりの流れについ て多くの研究が行われている3).

飛翔昆虫の多くは薄い平板翼を有しており，その前縁が 尖っている、そのため羽ばたき運動中は，はく離による安 定した前縁副(Leading-edge vortex)が観測させる.この前 緣渦は翅の上面に強い負圧領域を形成し，その力によって 昆虫は飛翔していると考えられている4)。さらに羽ばたき 運動では翅を単振動させた場合よりも，羽ばたきと同時に ひねり運動を加えた場合の方が大きな力が得られること がわかっている5)。これらのことから，昆虫の飛翔では羽 ばたき運動中の翅と渦の干渉及び翅のひ权り運動が重要 である. 本報告では, 実際の昆虫が発生する流体力を非定 常に計測するとともに, ダイナミック PIVを用いて翅まわ りの流れ場を可視化し，両者の同時計測を行った。これら
の計測結果から, 羽ばたき運動中の流体力と流れ場の関係 を定量的に評価することを試みる。

\section{2. 解析手法}

\section{1 解析対象}

飛翔昆虫を用いた実験として，トンボの周りの流れ場と 流体力の同時計測を行った。飛翔昆虫としてトンボを利用 したのは，トンボが比較的大型の部類に属する肉食の昆虫 であり，獲物を捕食するため飛行性能に優れているためで ある.また，トンボの羽ばたき周波数は約 $30 \mathrm{~Hz}$ であり， 非定常計測を行うことが比較的容易であることから，MAV 用の機構を作成しやすいなどの利点があげられる.

本研究で計測に用いたアキアカネ(学名)は, 初夏から晚 秋にかけて日本全国に広く生息し，捕獲も容易である.ア キアカネの緒言をTable 1に示す. 前翅と後翅の干涉を排 除し, 羽ばたき運動により発生する力を評価し易くするた め, 前翅あるいは後翅を切除して計測を行った. 前翅のみ のトンボをType A，後翅のみのトンボを Type B とした。

Table 1 Characteristics of Sympetrum frequens

\begin{tabular}{|c|c|c|c|}
\hline \multicolumn{2}{|c|}{ Length of body } & Type A & Type B \\
\hline \multicolumn{2}{|c|}{ Weight of body } & $43 \mathrm{~mm}$ & $44 \mathrm{~mm}$ \\
\hline \multirow{2}{*}{ Forewing } & Wing span & $33 \mathrm{~mm}$ & $0.28 \mathrm{~g}$ \\
\hline & Wing chord & $8.3 \mathrm{~mm}$ & - \\
\hline \multirow{2}{*}{ Hindwing } & Wing span & - & $32 \mathrm{~mm}$ \\
\hline \multicolumn{2}{|c|}{ Flapping frequency } & $27 \mathrm{~Hz}$ & $10 \mathrm{~mm}$ \\
\hline \multicolumn{2}{|c|}{ Wing chord } & - & $26 \mathrm{~Hz}$ \\
\hline
\end{tabular}




\section{2 流体力䂥測}

本研究では昆虫が発生する流体力を計測するため, カン チレバー(片持ち梁)とひずみゲージを用いて，トンボを固 定した状態で計測を行った.したがって，測定される流体 力はトンボが実際に飛行している状態 (フリー・フライト) の状態と必ずしも一致するわけではないが，昆虫が羽ばた くことによってどのような揚力が発生するかを調べるこ とは可能である.この状態で流体力を計測した結果，フリ 一フライトの状態とほぼ等しい揚力（トンボの自重の 1.2 倍）が得られることを確認済みである。

トンボの自重はおよそ $1.96 \mathrm{mN} \sim 2.94 \mathrm{mN}$ であり, 飛 行に必要な流体力は $9.81 \mathrm{mN}$ 程度であると想定される. このような小さな非定常力を計測する場合，ひずみゲージ の感度とカンチレバーの固有振動数が問題になる。トンボ の羽ばたき周波数は約 $30 \mathrm{~Hz}$ であることから，レバーの固 有振動数は共振を避けるため $60 \mathrm{~Hz}$ 以上の周波数が必要に なる.しかし，レバーの剛性を上げることで固有振動数を 上げると，ひずみゲージの感度が下がってしまう。このこ とから，相反する 2 つ条件を両立することが計測上重要 になる.そこで, レバーの材質や直径, 長さを調整して固 有振動数を上げるとともに，ゲージ率の高いひずみゲージ を用いて感度を上げ，これらの問題を解決した。開発した 流体力計測装置をFig. 1に，レバーの仕様をTable 2に示す.

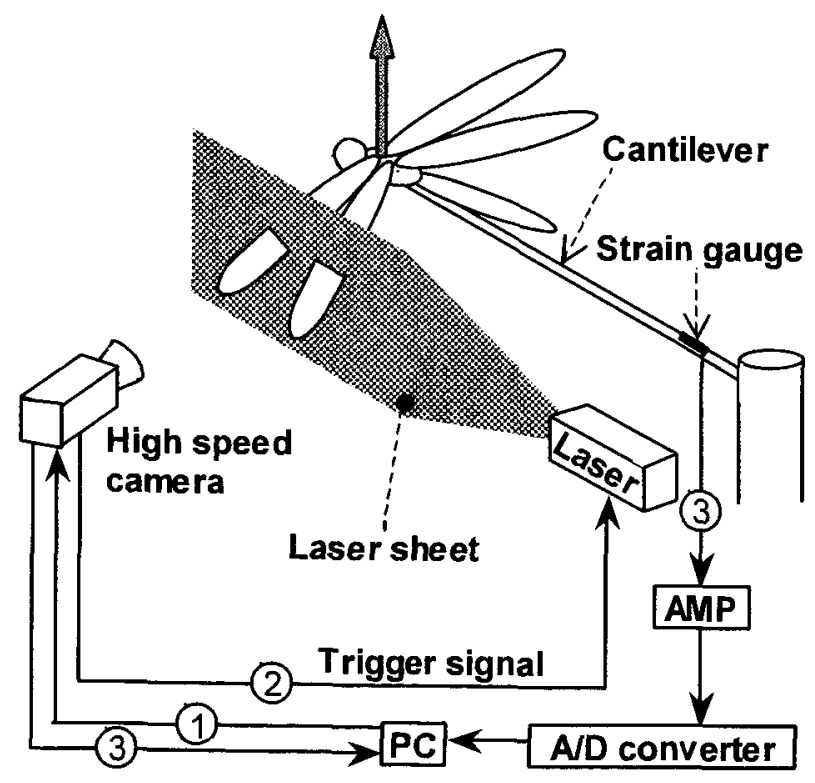

Fig. 1 Schematics of measurement system of aerodynamic force

Table 2 Specifications of micro load-cell system

\begin{tabular}{|c|c|}
\hline Material & Carbon rod \\
\hline Diameter & $1.0 \mathrm{~mm}$ \\
\hline Length & $75 \mathrm{~mm}$ \\
\hline Resonance frequency & $63 \mathrm{~Hz}$ \\
\hline Gauge factor & 104 \\
\hline
\end{tabular}

計測はレバーの先端にトンボを固定して行ったレバー の根元にひずみグージ(共和電業社製：ゲージ率 104)を貼 り付け，トンボが鉛直上向きに発生するカをレバーのひず みとして検出した，検出されたひずみはアンプによって 1000 倍に増幅し，PCにより記録した，実験では流体力の 絶対值が小さいため，ひずみダージの特性が温度に強く影 響する。そこで，ひずみゲージの周囲とブリッジ回路を断 熱材で覆い, 外気との接触を避ける処置を施した。 その結 果, $0.981 \mathrm{mN} \sim 9.81 \mathrm{mN}$ までの力を誤差土1\%以内の精 度で計測できることを確認した。また，ハンマリング試験 の結果, 計測系の固有振動数は $63 \mathrm{~Hz}$ であり, トンボの羽 ばたき周波数の約 2 倍を確保している。

\section{3 ダイナミック PIV 計測}

トンボの羽ばたき運動によって生じる渦度場を計測す るため, ダイナミック PIVシステムを使用した。

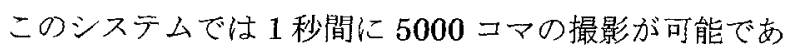
り，30 Hzで羽ばたくトンボの周囲の流れを計測すること が可能である.ダイナミック PIV システムと流体力計測シ ステムを同期させることにより，流れ場と流体力の同時計 測を実施した。

\section{3. 解析結果}

\section{1 流体力計測結果}

Fig. 2にトンボが発生する流体力及び翅のひねり角の計 測結果を示す. Fig. 2 (a) は前翅のみ, Fig. 2 (b) は後翅の みの結果である.計測結果は 5 周期分の位相平均結果であ る.羽ばたき運動における翅のひねり運動の効果を確認す るためひひ称り角(Feathering angle)を計測した。ひ衫り 角は前縁の軌跡(ストロークプレーン)上翅断面(翼弦方向) がな寸角とし, PIVの計測断面の前縁と後縁を時系列に追 跡することで計測した。

(a)では，位相 80 度付近で最大揚力(自重の約 3.5 倍)を 発生し, 下死点付近で最低揚力(自重の約-1.5 倍)を発生し た。ひ和り運動について見てみると，振り下げ時はストロ ークプレーンと翅を直角に近い角度(約 70 度)で一定に保 って㧍り,逆に振り上げ時は比較的平行に近い角度(約 150 度)を保っている。この様なひねり運動を行うことにより， 振り下げ時は前緣渦の発生を促進させ, 逆に振り上げ時は 抑制していると考えられる，揚力の時閒平均值は，自重の 約 0.53 倍であった。

(b)の場合，位相 120 度付近で最大揚力(自重の約 1.8 倍) を発生し，位相 240 度付近で最低揚力(自重の約-1.1倍)を 発生した。ひるり運動について見てみると，振り下げ時は ひ和り角約 30 度 70 度まで緩やかに翅をひねり, 逆に振 り上げ時はひねり角を約 120 度一定に保っている. 時閒平 均值は, 自重の約 0.18 倍であった。 


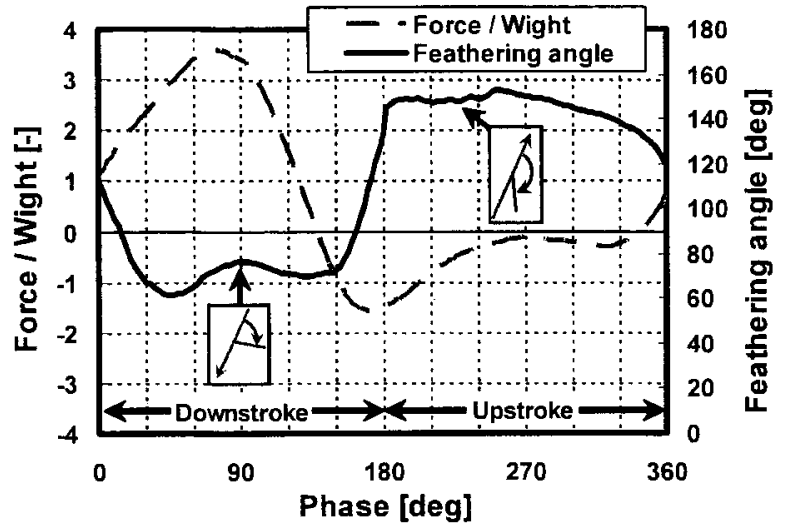

(a) Forewing: Type A

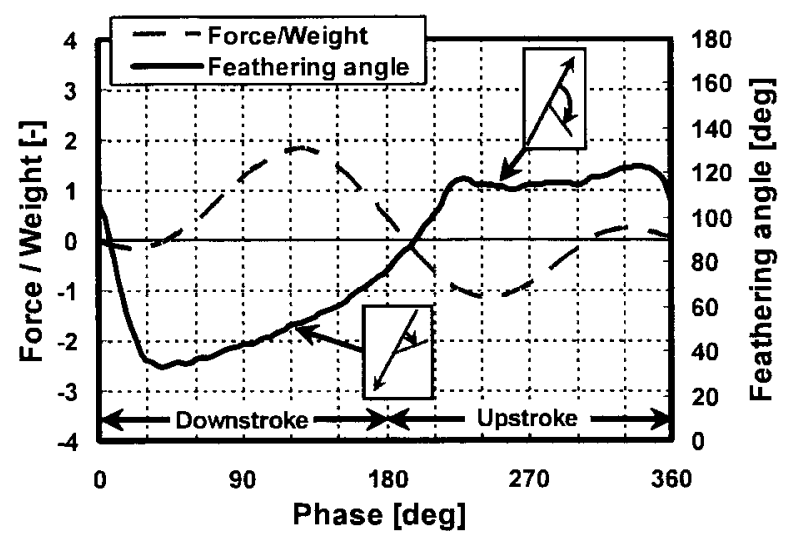

(b) Hindwing: Type B

Fig. 2 Comparison of aerodynamic force and feathering angle

\section{2 ダイナミックPIV 計測結果}

Fig. 3にトンボの翅のま放りの PIV 解析結果を示寸。こ こで, $(\mathrm{a}-1) \sim(\mathrm{b}-2)$ は前翅のみ, $(\mathrm{c}-1) \sim(\mathrm{d}-2)$ は後翅のみの 結果である。

Fig. $3(\mathrm{a}-1) ，(\mathrm{a}-2)$ は位相角 80 度付近における最大揚力 発生時の渦度コンター図と流れ場のベタトル図である。た だし，ベクトル図は翅に対する相对速度を示す，同様に (b-1)，(b-2)は下死点付近で揚力が最低となる場合の測定結 果である. 大きな揚力が得られている( $\mathrm{a}-1)$ では, 翅の前縁 ではく離した流れが観察される.トンボはこの前縁渦によ る負圧により揚力を得ている4)之考えられる。一方，揚力 が最低となる(b-1)に扔いても前縁渦が観察される。前縁 渦があるにも関わらず，揚力が発生しない原因としては， 下死点付近で羽ばたき速度が遅くなるため，振り下げによ り引きずられてきた流れが翅の上面に衝突するためと考 えられる.ベクトル図を見ると，(a-1)では翅に衝突するよ うな流れは観察されないが，(b-2)では流れが翅上面に衝突 する様子が観察された.このことが(b-1)において負の揚力 を発生させた原因と考えられる。

Fig. $3(\mathrm{c}-1) ，(\mathrm{c}-2)$ に位相角 120 度付近に扔ける最大揚力 発生時の渦度コンター図と流れ場のベクトル図を示す。 (d-1)，(d-2)以位相角度 240 度付近にお㚈る最低揚力発生
時の結果である。( $(\mathrm{c}-1)$ と(d-1)から，前翅のみの計測結果と 同様に前縁渦が発生していることがわかる。ここで $(\mathrm{c}-1)$ は翅の上面に渦があるのに対して, (d-1)では渦上翅との距 離が大きくなっている，翅を振り下げている(c-2)では，翅 に対して下から上に流れが衝突するため，上向きの力を発 生する.一方，振り上げ時( $\mathrm{d}-2)$ では翅に対して上がら下に 押し付讨る流れが発生するため，はく離渦による負圧の効 果が小さくなり正の揚力は発生しない.

\section{4. 結論}

羽ばたき翼による飛翔メカニズムを解明するため, トン ボが発生する流体力と翅まかりの流れ場を同時計測し，以 下の知見を得た。

（1）トンボは前翅のみの場合平均で自重の約 0.53 倍，後翅 のみの場合平均で自重の約 0.18 倍, 鉛直上向きの力を 発生する.

（2）振り下げ時はストロークプレーンと翅を直角に近く保 って羽ばたくことにより前縁渦を発生させ，逆に振り 上げ時は比較的平行に近く保つことで渦の発生を抑制 している.

（3）振り下げ時，前縁からはく離した流れによる前縁渦が 翅の上面に付着する様子を可視化した．流体力と比較 した結果，トンボはこの渦の負圧により大きな力を得 ていると考えられる。

\section{謝 辞}

本研究は文部科学省科学研究補助金(16560157)の援助 を得て行われた。ここに記して謝意を表す。

\section{参考文献}

1) Joel M. Grasmeyer, Matthew T. Keennon: Development of the Black Widow Micro Air Vehicle, FIXED AND FLAPPING WING AERODYNAMICS FOR MICRO AIR VEHICLE APPLICATIONS, Amer Inst of Aeronautics, Vol.195, (2001), pp.519-535.

2) Akira Azuma, Masato Okamoto, Kunio Yasuda: Aerodynamic Characteristics of Wings at Low Reynolds Number, FIXED AND FLAPPING WING AERODYNAMICS FOR MICRO AIR VEHICLE APPLICATIONS, Amer Inst of Aeronautics, Vol.195, (2001), pp.341-398.

3) Richard Ames, Oliver Wong Narayanan Komerath: On the Flowfield and Forces Generated by a Flapping Rectangular Wing at Low Reynolds Number, Proc. 6th KSME-JSME thermal and Fluid Engineering Conference, (2005), on CD-ROM.

4) Michael H. Dickinson, Fritz-Olaf Lehmann, Sanjay P. Sane, Wing Rotation and the Aerodynamic Basis of Insect Flight, SCIENCE, Vol.284, (1999), pp.1954-1960.

5) Mizuki Nakamura, et al., Correlation Between Vortex Structures and Aerodynamic Force in Insect's Flight, Proc. 6th KSME-JSME thermal and Fluid Engineering Conference, (2005), on CD-ROM. 
$\begin{array}{llllllllllllllll}\text { Vorticity. } & -10 & -9 & -7 & -6 & -4 & -3 & -1 & 0 & 1 & 3 & 4 & 6 & 7 & 9 & 10\end{array}$

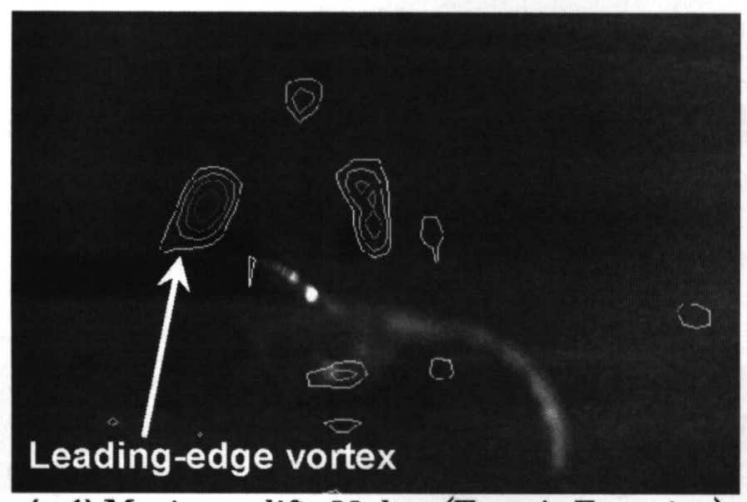

(a-1) Maximum lift: 80 deg. (Type A: Forewing)

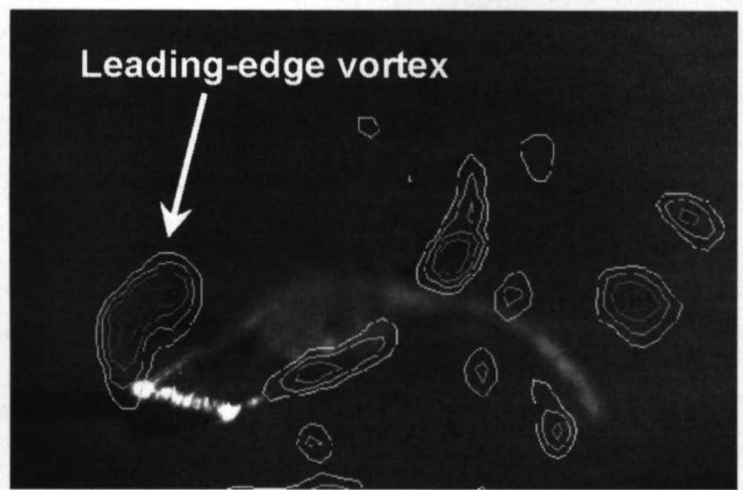

(b-1) Minimum lift: near the BDC (Type A: Forewing)

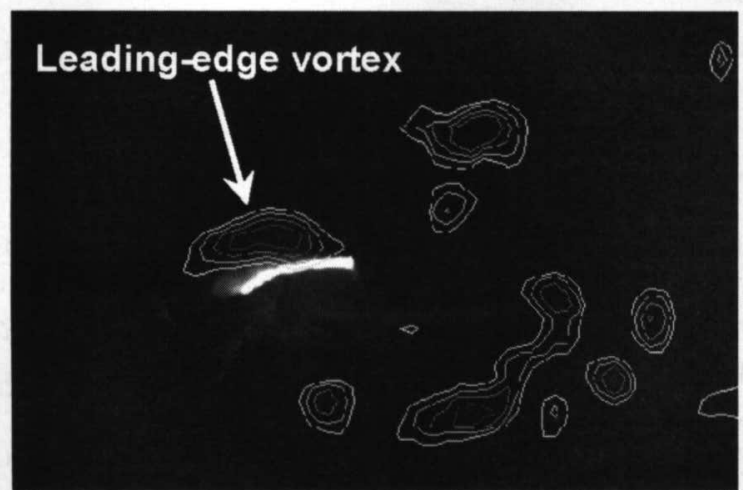

(c-1) Maximum lift: $120 \mathrm{deg}$. (Type B: Hindwing)

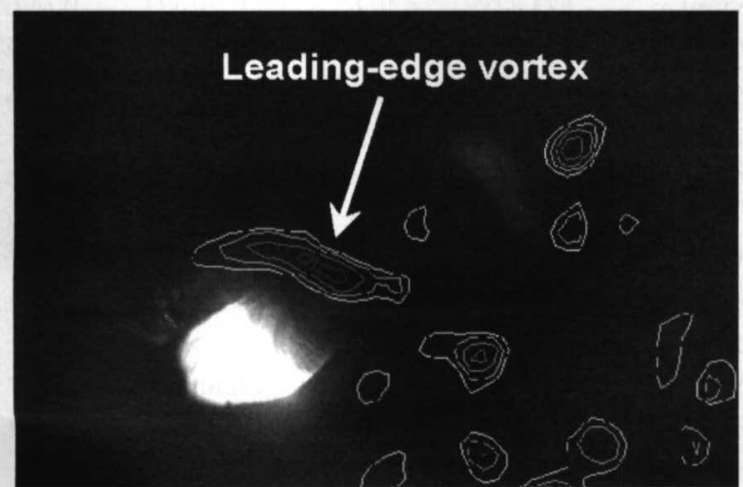

(d-1) Minimum lift: $240 \mathrm{deg}$. (Type B: Hindwing)

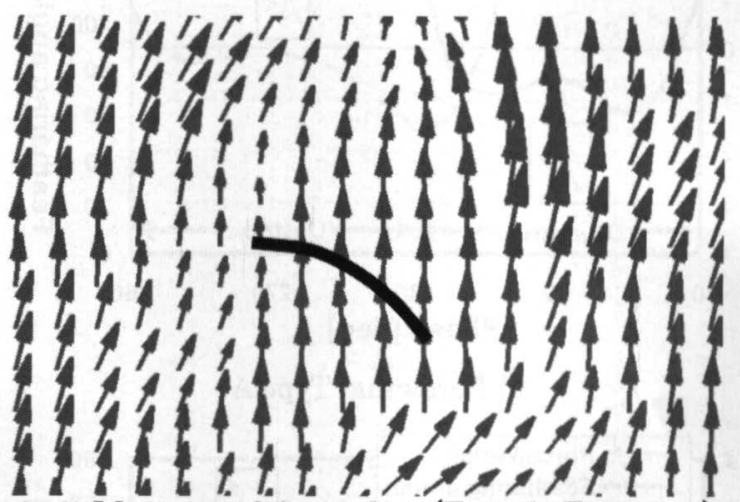

(a-2) Maximum lift: $80 \mathrm{deg}$. (Type A: Forewing)
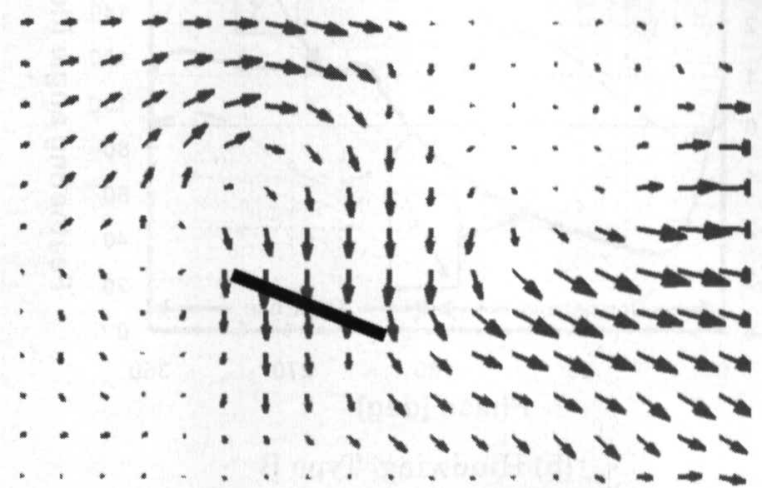

(b-2) Minimum lift: near the BDC (Type A: Forewing)

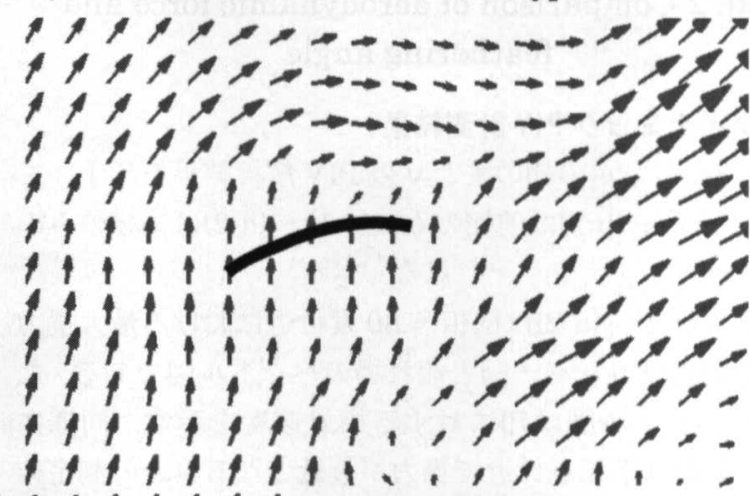

(c-2) Maximum lift: $120 \mathrm{deg}$. (Type B: Hindwing)

$11111+1,15 k+15+1$

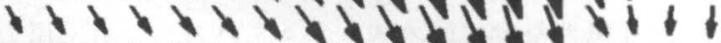

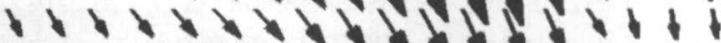

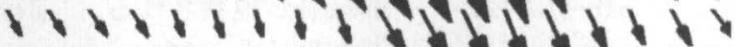
$111+1+1+1+1111+11$ $11+1+10+11+11+11$ $11+1+1+1+1+1,1+1$ $1+1+1+1+1+1+1,1+1$ $11+111+119+1,155$ $11+1+1+11+110$

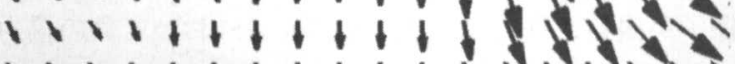
$1+11+1+1+1,151<1$ (d-2) Minimum lift: $240 \mathrm{deg}$. (Type B: Hindwing)

Fig. 3 Flow fields around a dragonfly (Left: Vorticity contour, Right: Velocity vector) 